\title{
First zoeal stage of Processidae (Decapoda, Caridea): review and new descriptions of Ambidexter symmetricus Manning and Chace 1971 and Processa fimbriata Manning and Chace 1971
}

\author{
Mariana Terossi · Fernando Luis Mantelatto
}

Received: 27 September 2013/Revised: 25 April 2014/ Accepted: 11 June 2014/Published online: 24 June 2014

(C) Springer-Verlag Berlin Heidelberg and AWI 2014

\begin{abstract}
This study reviews the morphology of the first zoeal stage of the pantropical and subtropical marine shrimps of the family Processidae. We present the first descriptions of the zoea I of Ambidexter symmetricus and Processa fimbriata and compare them with available published descriptions, in order to detect patterns to differentiate the genera. Among the species of Processidae, the zoea I of Ambidexter can be differentiated by the presence of a rostrum, and the resemblance to Nikoides and Processa, previously reported for adults, is now confirmed for the larval morphology. Based on the new descriptions, $A$. symmetricus and A. panamensis can be easily separated by four independent larval characters: anterior tubercle on the carapace (present in A. panamensis and absent in A. symmetricus), the antennal scale (segmented distally in $A$. panamensis and unsegmented in A. symmetricus), and the anal spine and second pereiopod (absent in A. panamensis and present in A. symmetricus). P. fimbriata can be separated from the other 11 species of Processa by means of two larval characters: 4 aesthetascs on the exopod of the antennules, and the presence of an anal spine.
\end{abstract}

Keywords Larval Processa $\cdot$ Ambidexter $\cdot$ Processidae

Communicated by H.-D. Franke.

M. Terossi · F. L. Mantelatto $(\square)$

Laboratory of Bioecology and Crustacean Systematics (LBSC), Postgraduate Program in Comparative Biology, Department of Biology, Faculty of Philosophy, Sciences and Letters at Ribeirão Preto (FFCLRP), University of São Paulo (USP), Av.

Bandeirantes - 3900, Ribeirão Preto, SP CEP 14040-901, Brazil

e-mail: flmantel@usp.br

M. Terossi

e-mail: mterossi@usp.br

\section{Introduction}

The family Processidae Ortmann 1896 comprises 68 recognized species, in five genera (De Grave and Fransen 2011): Ambidexter Manning and Chace 1971 (3 species), Clytomanningus Chace 1997 (2), Hayashidonus Chace 1997 (1), Nikoides Paul'son 1875 (10), and Processa Leach 1815 (52). Shrimps of this family are small, nocturnal, and abundant in marine shallow-water habitats, primarily on grass flats and in tide pools in pantropical and subtropical regions; some are components of the offshore fauna (Manning and Chace 1971; Chace 1997).

This family is represented in Brazil by seven species (Christoffersen 1998): Ambidexter symmetricus Manning and Chace 1971, Processa bermudensis (Rankin 1900), P. brasiliensis Christoffersen 1979, P. fimbriata Manning and Chace 1971, P. guyanae Holthuis 1959, P. hemphilli Manning and Chace 1971, and P. profunda Manning and Chace 1971. The morphology of the first zoeal stage is known only for $P$. bermudensis, described by Gurney (1936) from larvae from Bermuda.

Here, we describe the zoea I of Ambidexter symmetricus and Processa fimbriata. We also review the morphology of the first zoeal stage of the family Processidae, using all descriptions available in the literature, in order to detect patterns to differentiate the genera.

\section{Materials and methods}

An ovigerous female of Ambidexter symmetricus was collected in June 2006 at Araçá Beach (São Sebastião, State of São Paulo, Brazil, $23^{\circ} 48^{\prime} \mathrm{S}, 45^{\circ} 24^{\prime} \mathrm{W}$ ) by hand in a rocky intertidal area. An ovigerous female of Processa fimbriata was collected on November 2002 on the infralittoral rocky 
shores of East Beach, Anchieta Island (Ubatuba, State of São Paulo, Brazil, $23^{\circ} 33^{\prime} \mathrm{S}, 45^{\circ} 05^{\prime} \mathrm{W}$ ) by SCUBA diving.

Both females were maintained in containers with natural sea water until the zoeae hatched. Actively swimming larvae were conserved in $4 \%$ formaldehyde. For each species, the number of hatches was counted, and 10 larvae were measured and drawn. The carapace length (CL) of the larvae and ovigerous females was measured as the maximum length from the posterior margin of the ocular orbit to the posterior margin of the carapace. Appendages were dissected under a Zeiss Stemi SV6 stereomicroscope, and drawings and measurements were taken using a Leica DM1000 microscope equipped with a camera lucida. Larval descriptions and setal counts follow the method proposed by Clark et al. (1998), and we use the setal terminology suggested by Landeira et al. (2009). In Fig. $2 \mathrm{~d}-\mathrm{f}$, the setae are drawn truncated, because they are the same as the setae in Fig. 2a-c. Voucher maternal specimens and larvae were deposited at the Crustacean Collection of the Biology Department of FFCLRP, University of São Paulo, Brazil (CCDB/FFCLRP/USP, accession numbers: 3495 for $A$. symmetricus and 3501 for $P$. fimbriata).

\section{Results}

The parental females of Ambidexter symmetricus and Processa fimbriata collected measured 5.7 and $4.6 \mathrm{~mm}$ in $\mathrm{CL}$, respectively, and the number of hatched larvae was 127 and 93, respectively.

\section{Morphological description}

\section{Ambidexter symmetricus Manning and Chace 1971 Zoea I}

Carapace length: $\quad 0.35 \pm 0.02 \mathrm{~mm}(n=10)$.

Cephalothorax (Fig. 1a): Supraorbital spines absent, pterygostomian spine present; 4 denticles on anteroventral margin; rostrum slender, without teeth, and short, not overreaching the extremity of the antennular peduncle.

Antennule (Fig. 1b): Peduncle unsegmented; endopod as a long plumose seta; exopod with 4 terminal aesthetascs and 1 plumose inner terminal seta.

Antenna (Fig. 1c): Peduncle with an inner spiny projection near the endopod; endopod unsegmented, wider proximally and with two equal rows of spines in the mediodistal region; exopod (antennal scale) unsegmented, with 12 setae arranged as 9 plumose setae +1 simple seta +2 plumose setae.

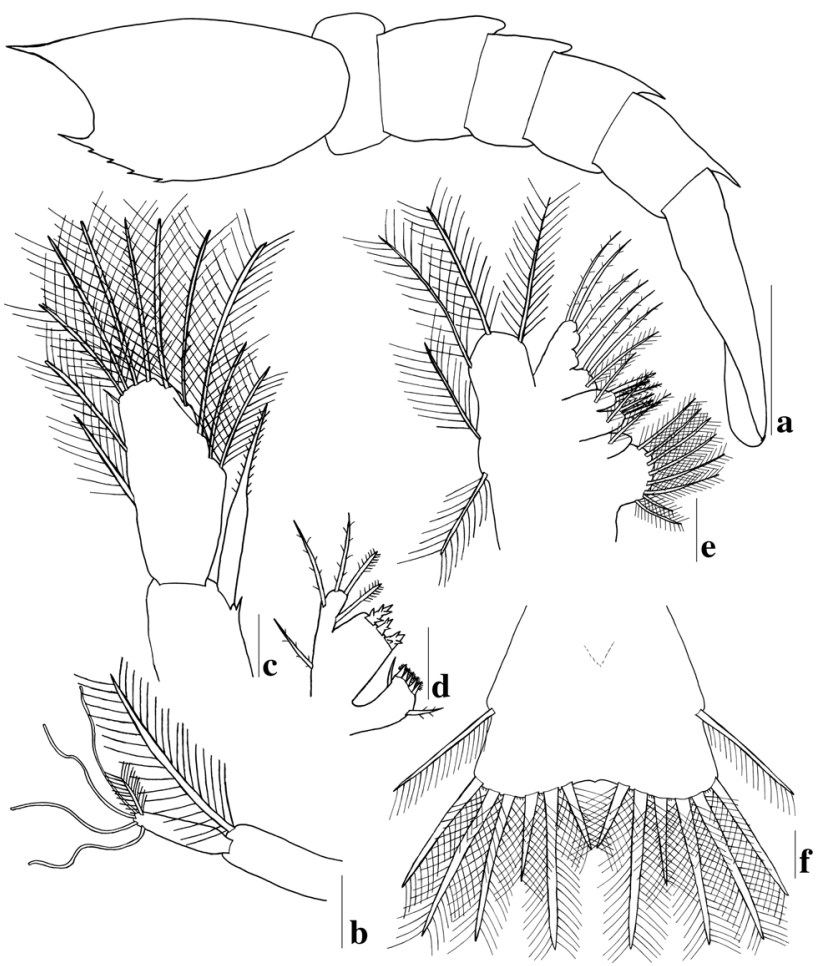

Fig. 1 Ambidexter symmetricus. Zoea I. (a) Lateral view; (b) antennule; $(c)$ antenna; $(d)$ maxillule; $(e)$ maxilla; and $(f)$ telson. Scale bars (a) $0.2 \mathrm{~mm},(b-f) 0.05 \mathrm{~mm}$

Mandible: With an incisor and well-developed molar processes, without palp.

Maxillule (Fig. 1d): Coxal endite with 7 setae (1 sparsely plumose, 5 sparsely hardy plumose and 1 simple); basial endite with 3 plumodenticulate cuspidate setae; endopod unsegmented, with 3 terminal setae ( 2 sparsely plumose and 1 sparsely hardy plumose) and 1 sparsely hardy plumose lateral seta; exopodal seta present.

Maxilla (Fig. 1e): Coxal endite bilobed, with 8 plumose marginal setae on proximal lobe and 1 plumose marginal seta on distal lobe; basial endite bilobed, with 4 setae ( 3 sparsely hardy plumose marginal and 1 plumose submarginal) on each lobe; endopod with 4 lobes with 3 ( 1 plumose and 2 sparsely plumose), 1 (sparsely plumose), 1 (sparsely plumose), and 2 (sparsely plumose) setae, respectively; exopod (scaphognathite) with 5 plumose marginal setae.

First maxilliped (Fig. 2a): Coxa with 3 marginal setae (1 short simple, 1 sparsely plumose, and 1 plumose) arranged as $(2+1)$; basis with 12 setae arranged in 4 groups, the proximal group with 1 plumose marginal seta, the next groups with 4 ( 1 short simple submarginal and 3 sparsely plumose marginal), and 3 (1 short simple submarginal and 2 sparsely plumose marginal) setae, and the distal one with 3 (1 short simple submarginal, 1 simple marginal, and 1 sparsely plumose marginal) setae; endopod 4-segmented, 


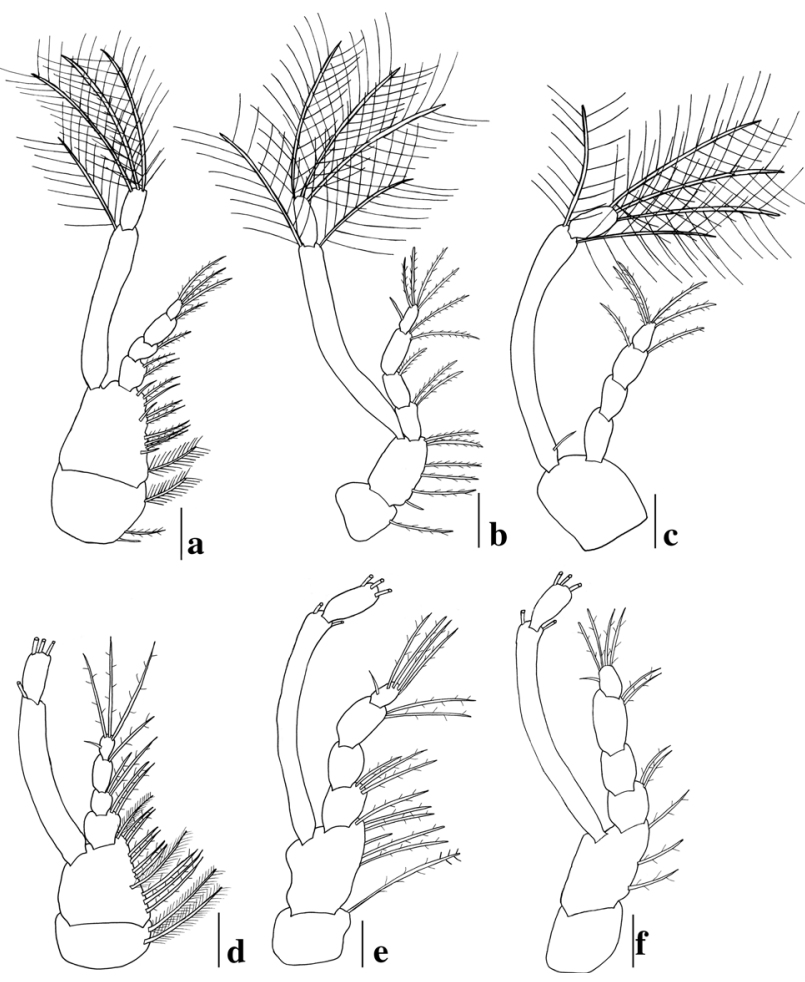

Fig. 2 Zoea I. $a, b, c$ Ambidexter symmetricus. $d$, e, $f$ Processa fimbriata. $(a, d)$ First maxilliped; $(b, e)$ second maxilliped; and $(c, f)$ third maxilliped. Scale bars $0.05 \mathrm{~mm}$. Plumose natatory setae of $P$. fimbriata are as those in A. symmetricus

with 2 (1 marginal and 1 terminal), 1 (terminal), 1 (terminal), and 3 (terminal) sparsely plumose setae, respectively; exopod 2 -segmented with 1,3 plumose terminal natatory setae.

Second maxilliped (Fig. 2b): Coxa with 1 marginal sparsely plumose seta; basis with 1 short simple marginal seta and 5 sparsely plumose marginal setae $(1+1+1+2)$; endopod 4-segmented, with 2 (sparsely plumose terminal), 1 (sparsely plumose terminal), 2 (sparsely plumose terminal), and 5 (4 sparsely plumose terminal and 1 simple marginal) setae, respectively; exopod 2-segmented, with 2, 3 plumose natatory setae.

Third maxilliped (Fig. 2c): Coxa and basis without setae; endopod 4-segmented, with $0,0,2,4$ sparsely plumose terminal setae, respectively; exopod 2-segmented, with 2,3 plumose natatory setae.

Pereiopods: Buds of first and second pereiopods present.

Abdomen (Figs. 1a, 4a): With 5 somites without setae, pair of posterodorsal spines on somites 4 and 5; anal spine present (Fig. 1f).

\section{Pleopods and uropods: Absent.}

Telson (Figs. 1f, 4a): Broad at posterior margin, with $7+7$ setae (inner 5 plumose, outer 2 laterally plumose

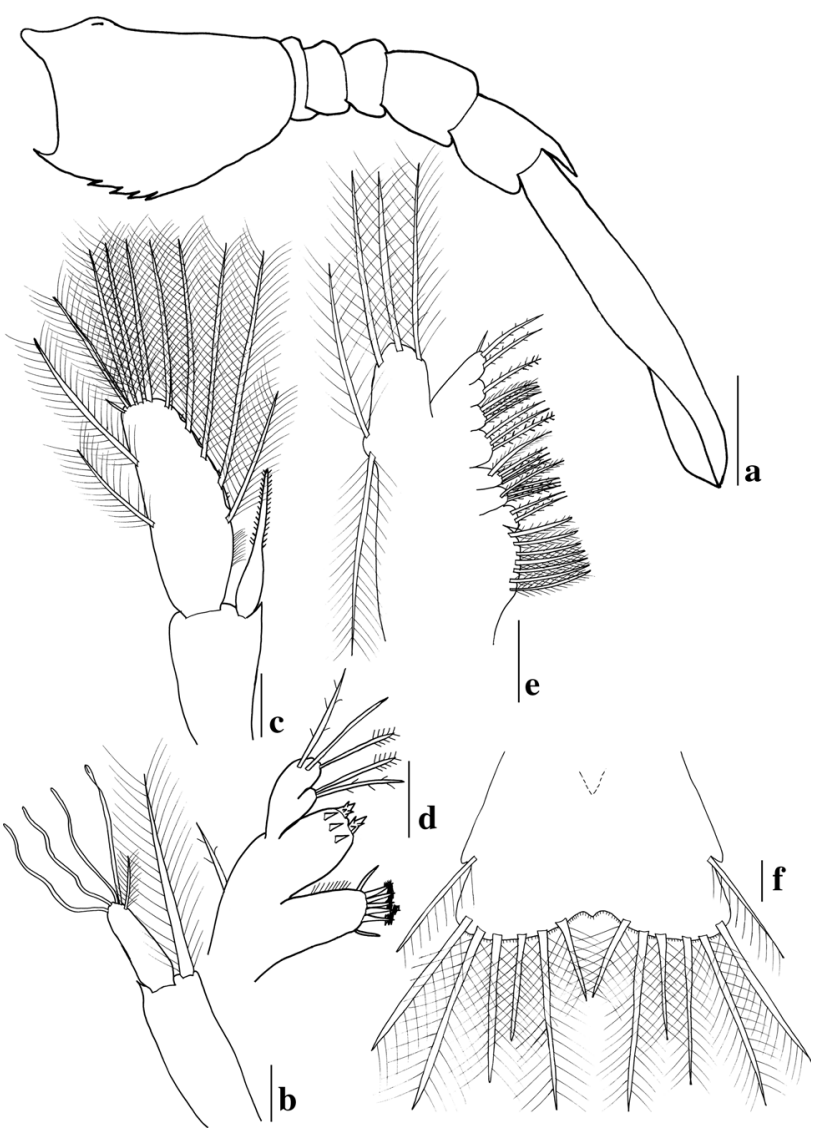

Fig. 3 Processa fimbriata. Zoea I. (a) Lateral view; (b) antennule; (c) antenna; (d) maxillule; (e) maxilla; and $(f)$ telson. Scale bars (a) $0.2 \mathrm{~mm},(b-f) 0.05 \mathrm{~mm}$

setae), outer pair of setae subterminal; one row of spinules on distal margin and around bases of the $6+6$ inner setae.

\section{Processa fimbriata Manning and Chace 1971 Zoea I}

Carapace length: $\quad 0.42 \pm 0.01 \mathrm{~mm}(n=10)$

Cephalothorax (Fig. 3a): With an anterior tubercle, supraorbital spines absent, pterygostomian spine present; anteroventral margin with 4 denticles. Without rostrum.

Antennule (Fig. 3b): Peduncle unsegmented, with outer spiny projection near exopod; endopod as a long plumose seta; exopod with 4 terminal aesthetascs and 1 plumose inner terminal seta.

Antenna (Fig. 3c): Peduncle with inner spiny projection near endopod; endopod unsegmented, wider proximally and with two equal rows of spines in mediodistal region; exopod (antennal scale) unsegmented, with 12 setae, arranged as 9 plumose setae +1 simple seta +2 plumose setae. 
Mandible: With incisor and well-developed molar processes, without palp.

Maxillule (Fig. 3d): Coxal endite with 7 setae (1 simple, 5 sparsely hardy plumose, and 1 simple) and microtrichia; basial endite with 2 plumodenticulate cuspidate setae and 3 spiniform setae; endopod bilobed, with 2 terminal (1 sparsely plumose and 1 sparsely hardy plumose) setae on proximal lobe and 3 ( 2 subterminal, 1 simple, and 1 sparsely plumose; and 1 terminal sparsely hardy plumose) setae on distal lobe; exopodal seta present.

Maxilla (Fig. 3e): Coxal endite bilobed, with 7 plumose marginal setae on proximal lobe and 2 sparsely plumose marginal setae on distal lobe; basial endite bilobed, with 4 setae ( 3 sparsely hardy plumose marginal and 1 plumose submarginal) on each lobe; endopod with 4 lobes, with 3 (2 sparsely plumose and 1 sparsely hardy plumose), 3 (2 plumose and 1 sparsely plumose), 1 (sparsely hardy plumose), and 3 ( 2 sparsely plumose and 1 simple) marginal setae, respectively; exopod (scaphognathite) with 5 plumose marginal setae.

First maxilliped (Fig. 2d): Coxa with 2 plumose marginal setae; basis with 11 setae arranged in 4 groups, proximalmost group with 3 sparsely plumose marginal setae, next 2 groups with 3 ( 1 plumose submarginal and 2 sparsely plumose marginal) and 2 sparsely plumose marginal setae, and distalmost group with 3 ( 2 sparsely plumose marginal and 1 plumose marginal) setae; endopod 4-segmented, with 2 (sparsely plumose terminal), 2 (sparsely plumose terminal), 1 (sparsely plumose terminal), and 4 ( 3 sparsely plumose terminal and 1 short simple marginal) setae, respectively; exopod 2-segmented, with 1, 3 plumose terminal natatory setae.

Second maxilliped (Fig. 2e): Coxa with 1 sparsely plumose marginal seta; basis with 1 short simple marginal seta and 5 sparsely plumose marginal setae (arranged as $2+1$ simple +3 ); endopod 4-segmented, with 3 (sparsely plumose terminal), 0,2 (sparsely plumose terminal), and 5 (4 sparsely plumose terminal and 1 simple marginal) setae, respectively; exopod 2-segmented, with 2, 3 plumose natatory setae.

Third maxilliped (Fig. 2f): Coxa without setae; basis with 3 sparsely plumose marginal setae; endopod 4-segmented, with 2 (sparsely plumose terminal), 0, 2 (sparsely plumose terminal), and 5 (4 sparsely plumose terminal and 1 simple marginal) setae, respectively; exopod 2-segmented, with 2 , 3 plumose natatory setae.

Pereiopods: Buds of first pereiopod present.

Abdomen (Figs. 3a, 4b): With 5 somites without setae, pair of posterodorsal spines on somite 5; anal spine present (Fig. 3f).

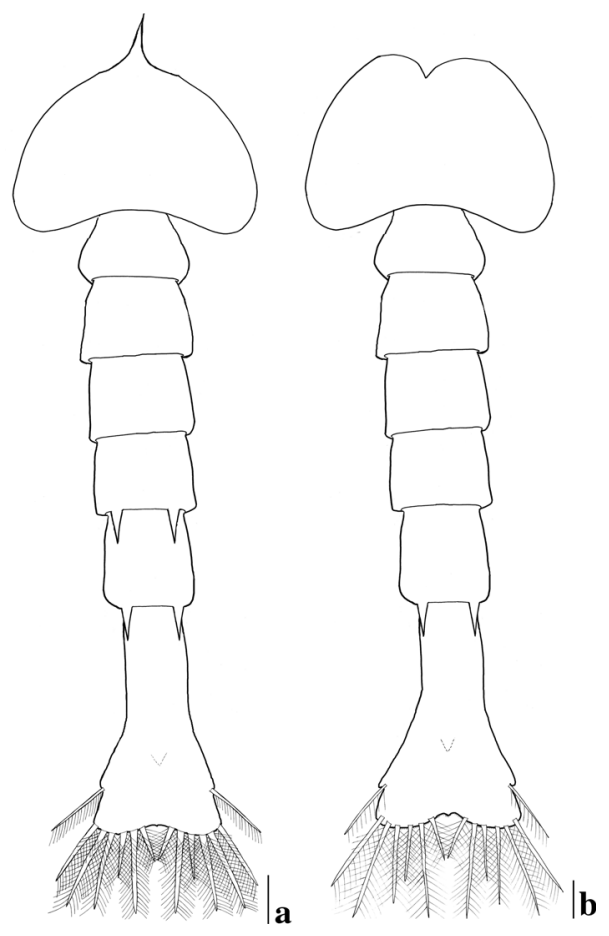

Fig. 4 Zoea I. dorsal view. a Ambidexter symmetricus. $b$ Processa fimbriata. Scale bars $0.10 \mathrm{~mm}$

Pleopods and uropods: Absent.

Telson (Figs. 3f, 4b): Broad at posterior margin, with $7+7$ setae (inner 5 plumose, outer 2 laterally plumose), the 2 outermost setae subterminal; one row of spinules on distal margin and around bases of the $6+6$ inner setae.

\section{Discussion}

The first zoeal stage of shrimps of the family Processidae is presently known for only 15 species, including the two studied here (Table 1). There are no data on the first zoeal stages of the genera Clytomanningus and Hayashidonus.

Based on the few descriptions then available, Gurney $(1937,1942)$ listed generic characteristics of zoea I of the family Processidae: carapace without rostrum; anterior margin of carapace serrated; antennal scale unsegmented; maxillule with exopodal seta; and abdominal segment 5, and sometimes also segment 4 , with a pair of posterodorsal spines. Some of these characters can no longer be considered as diagnostic (Table 1), because zoea I of Ambidexter has the rostrum present, and four taxa (A. panamensis, $P$. modica modica, $P$. modica carolii, and $P$. nouveli holthuisi) have the antennal scale segmented.

Some authors (Gurney 1923; Lebour 1936; Ortega et al. 2005) have suggested that larvae of Processidae resemble those of the family Hippolytidae Bate 1888. According to 
Table 1 Morphological characters of the first zoeal stage described for species of the family Processidae

\begin{tabular}{|c|c|c|c|c|c|c|c|c|c|c|c|c|c|c|c|}
\hline Characters & A_pa & A_sy & N_da & P_ae & P_be & P_ca & P_co & P_ec & P_ee & $P_{-}$fr & P_ma & P_mm & P_mc & P_nh & P_nn \\
\hline Reference & 1 & 2 & 3 & 3 & 4 & 5 & 6 & 7 & 8 & 2 & 9 & 10 & 10 & 10 & 11 \\
\hline Number of larval stages & 8 & $?$ & 9 & 9 & 8 & 9 & 10 & $?$ & $?$ & $?$ & 9 & 7 & 9 & 9 & 9 \\
\hline Rostrum & + & + & - & - & - & - & - & - & - & - & - & - & - & - & - \\
\hline Anterior tubercle on carapace & + & - & $?$ & $?$ & $?$ & + & + & + & + & + & + & + & + & + & + \\
\hline $\begin{array}{l}\text { Denticles on anteroventral } \\
\text { margin of carapace }\end{array}$ & $3-6$ & 4 & $2-3$ & $2-3$ & $?$ & $?$ & 3 & 2 & $?$ & 4 & $3-4$ & 4 & 4 & $3-4$ & $3-6$ \\
\hline $\begin{array}{l}\text { Aesthetascs on exopod } \\
\text { of antennule }\end{array}$ & $3-4$ & 4 & $?$ & $?$ & $?$ & 3 & 3 & 3 & 3 & 4 & 3 & 3 & 3 & 3 & 3 \\
\hline Antennal scale & $\mathrm{s}$ & $\mathrm{u}$ & $\mathrm{u}$ & $\mathrm{U}$ & $\mathrm{u}$ & $\mathrm{u}$ & $\mathrm{u}$ & $\mathrm{u}$ & $\mathrm{u}$ & $\mathrm{u}$ & $\mathrm{u}$ & $\mathrm{s}$ & $\mathrm{s}$ & $\mathrm{s}$ & s \\
\hline $\begin{array}{l}\text { Plumose setae on antennal } \\
\text { scale }\end{array}$ & 11 & 11 & 12 & 12 & 11 & 11 & 11 & 12 & 11 & 11 & 11 & 11 & 11 & 11 & 11 \\
\hline Exopodal seta on maxillule & + & + & $?$ & $?$ & + & $?$ & + & + & + & + & + & $?$ & + & + & + \\
\hline $\begin{array}{l}\text { Setae on distal segments } \\
\text { of exopod of Mxlp1 }\end{array}$ & 4 & 4 & 4 & 4 & $?$ & 5 & 5 & 4 & $?$ & 4 & 4 & 4 & 4 & 4 & 4 \\
\hline $\begin{array}{l}\text { Dorsal spine on abdominal } \\
\text { segment } 3\end{array}$ & - & - & - & + & - & - & - & - & - & - & - & - & - & - & - \\
\hline $\begin{array}{l}\text { Abdominal segment with pair } \\
\text { of posterodorsal spines }\end{array}$ & 4,5 & 4,5 & 5 & 5 & 5 & 4,5 & 5 & 5 & 5 & 5 & 5 & 5 & 5 & 5 & 5 \\
\hline Anal spine & - & + & $?$ & $?$ & $?$ & $?$ & $?$ & $?$ & $?$ & + & $?$ & $?$ & $?$ & - & - \\
\hline Pereiopod buds & 1 & 1,2 & 1 & 1 & 1 & $?$ & 1,2 & 1,2 & $?$ & 1 & 1 & 1 & 1 & $?$ & $?$ \\
\hline Setae on telson & $\mathrm{a}$ & $\mathrm{b}$ & $?$ & $?$ & $\mathrm{a}$ & $\mathrm{b}$ & $\mathrm{a}$ & $\mathrm{b}$ & $\mathrm{b}$ & $\mathrm{b}$ & $\mathrm{b}$ & $\mathrm{a}$ & $\mathrm{a}$ & $\mathrm{a}$ & $\mathrm{a}$ \\
\hline
\end{tabular}

Codes used for species: A_pa-Ambidexter panamensis Abele 1972; A_sy-Ambidexter symmetricus Manning and Chace 1971; N_daNikoides danae Paul'son 1875; P_ae—Processa aequimana (Paul'son 1875); P_be—Processa bermudensis (Rankin 1900); P_ca-Processa canaliculata Leach 1815; P_co-Processa compacta Crosnier 1971; P_ec_-Processa edulis crassipes Nouvel and Holthuis 1957; P_eeProcessa edulis edulis (Risso 1816); P_fr_Processa fimbriata Manning and Chace 1971; P_ma_Processa macrodactyla Holthuis 1952; P_mm-Processa modica modica Williamson in Williamson and Rochanaburanon 1979; P_mc_Processa modica carolii Williamson in

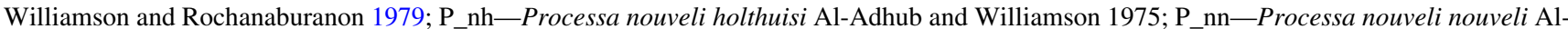
Adhub and Williamson 1975. References: 1-Williamson 1980; 2-present study; 3-Gurney 1937; 4-Gurney 1936; 5-Lebour 1936; 6Jagadisha and Sankolli 1977 (as P. barnardi); 7-Gurney 1923 (as P. canaliculata); 8-Gurney 1942; 9-González-Gordillo and Rodríguez 2000, Ortega et al. 2005; 10-Williamson and Rochanaburanon 1979; 11-according to Santos 1999 (we did not have access to the original description: Barnich 1996). Characters: +, present; -, absent; ?, data not available; s, segmented; u, unsegmented; a, $7+7$; b, (2 laterally plumose setae +5 plumose setae $)+(2$ laterally plumose setae +5 plumose setae $)$

Ortega et al. (2005), the larvae of these families can be differentiated by two main characters: (1) The distance between the bases of the antennules is greater than the width of each antennule in Processidae and (2) the presence of an anal spine in the first zoea in Hippolytidae. However, here, we report the presence of an anal spine in A. symmetricus and P. fimbriata, both members of Processidae, and many species of Hippolytidae do not have an anal spine (Terossi et al. 2010).

Except for the first character noted by Ortega et al. (2005), a comparison of these two families (Table 2) reveals no additional characters that can distinguish their larvae. The larvae of Hippolytidae show a wide range of variation (see review by Terossi et al. 2010), which encompasses the variation shown by larvae of Processidae (Table 2). There are two feasible explanations for this: (1) The family Hippolytidae is more diverse and has almost five times the number of recognized species as Processidae; (2) some species of Hippolytidae have abbreviated development, which usually leads to some morphological differences in the first zoeal stage, such as having more than seven pairs of setae on the telson, more than five setae on the scaphognathite, and more pereiopod buds (see review by Terossi et al. 2010).

The number of larval stages ranges from seven to ten in the family Processidae (Table 1), which indicates extended development. The only species with an unknown number of larval stages are A. symmetricus and $P$. fimbriata; however, considering their larval morphology (zoea I), they probably show extended development.

Based on the present review, it is possible to form conjectures about the zoeal morphology for genera of Processidae. Adults of the genus Ambidexter have a peculiar character, whereas other members of the family Processidae have only one pereiopod 1 chelate (usually the right) and the other with a simple dactyl, the species of Ambidexter have both pereiopods 1 symmetrically chelate (Chace 1997). This may well represent the ancestral condition in the Processidae (Williamson 1980). We also observed an 
Table 2 Comparison of some characters of Zoea I from families Processidae and Hippolytidae

\begin{tabular}{|c|c|c|}
\hline Characters & Processidae & Hippolytidae \\
\hline Number of recognized species & 68 & 318 \\
\hline $\begin{array}{l}\text { Number of species with first zoeal } \\
\text { stage known }\end{array}$ & 15 & $66^{\mathrm{a}}$ \\
\hline Dorsal tubercles on carapace & Absent or 1 & Absent, 1 or 2 \\
\hline $\begin{array}{l}\text { Distance between bases of } \\
\text { antennules in relation to } \\
\text { width of each antennule }\end{array}$ & Longer & Shorter \\
\hline Plumose setae on antennal scale & 11 or 12 & $9-14$ \\
\hline Plumose setae on scaphognathite & 5 & $3-35$ \\
\hline $\begin{array}{l}\text { Abdominal segments with } \\
\text { dorsolateral spines }\end{array}$ & $\begin{array}{l}4 \text { and } 5 \text {, or } \\
\text { only } 5\end{array}$ & $\begin{array}{l}\text { Absent, } 4 \text { and } \\
5 \text {, or only } 5\end{array}$ \\
\hline Pereiopod buds & 1 or 2 & Absent or $1-5$ \\
\hline Pairs of setae on telson & 7 & $7-10$ \\
\hline Abbreviated development & Not reported & Present \\
\hline
\end{tabular}

Data for latter family from Terossi et al. (2010), ${ }^{a}$ until 2010; ${ }^{b}$ according to Ortega et al. (2005). Number of recognized species according to De Grave and Fransen (2011)

exclusive character (presence of a rostrum) for the first zoeal stage of species of Ambidexter (Table 1).

There are three recognized species of the genus Ambidexter (De Grave and Fransen 2011): A. panamensis, A. swifti Abele 1972, and A. symmetricus. At present, only the morphology of zoea I of A. swifti remains unknown (Table 1). The other two species show some differences in the morphology of the first zoea (Table 1), in the anterior tubercle on the carapace (present in $A$. panamensis and absent in A. symmetricus), the antennal scale (segmented distally in A. panamensis and unsegmented in A. symmetricus), and the anal spine and second pereiopod (absent in A. panamensis and present in $A$. symmetricus).

The larval development of A. panamensis was described by Williamson (1980), who stated that no other potentially unique generic-level larval character had been discovered, besides the relatively large exopodal seta on the maxillule in the late zoeal stages. We propose that among the first zoea larvae of Processidae, the presence of a rostrum is exclusive to the genus Ambidexter.

The presence of posterodorsal spines on abdominal segment 4 of the first zoea was reported for the genus Ambidexter, and curiously also for $P$. canaliculata (Table 1). In her description of the first zoeal stage of $P$. canaliculata, Lebour (1936) provided an illustration of these spines, which leaves no doubt as to their existence. Probably, this structure is present in other unknown larvae of the genus Processa. Gurney (1923) also reported the larval stages of $P$. canaliculata; however, the zoea that he described was actually the larvae of two species, the early stages of $P$. edulis crassipes and the later stages of $P$. nouveli holthuisi (Fincham and Williamson 1978; Williamson and Rochanaburanon 1979).

The zoea I stages of Nikoides and Processa share the lack of a rostrum (Table 1). According to our observations, these genera cannot be separated based on their larval morphology (Table 1). In addition, the adults are extremely similar and can be differentiated only by the absence (Processa) or presence (Nikoides) of exopods in pereiopod 1 (Manning and Chace 1971; Chace 1997). Despite the morphological resemblance of both adults and larvae in Processa and Nikoides, the molecular phylogeny of Caridea proposed by Bracken et al. (2009) showed Processa as a sister group of Ambidexter, and Nikoides fell outside this group. In order to clarify the relationships between the genera of Processidae, further studies on the morphology (adults and larvae) and genetic data of these species, also including the genera Clytomanningus and Hayashidonus, will be needed.

For the genus Nikoides, the first zoea is known for only one species (Table 1). Among the described species, $N$. danae shares more characters with $P$. aequimana and $P$. edulis crassipes than with the other species (Table 1): 2-3 denticles on the anteroventral margin of the carapace ( 2 in $P$. edulis crassipes), antennal scale unsegmented, and 12 plumose setae on the margin of the antennal scale. This similarity is not associated with the geographic distribution, because $N$. danae and $P$. aequimana were both collected in the Red Sea, and P. edulis crassipes was collected in the English channel.

The first zoeal stage of Processa shows extensive variation, and four species have characters that are not shared by the other species of this genus (Table 1 ): P. compacta and $P$. canaliculata have 5 setae on the distal segments of the exopod of maxilliped 1 , and the other species have $4 ; P$. aequimana has a small dorsal spine on abdominal segment 3 , and the others lack dorsal spines at this location; $P$. edulis crassipes and $P$. compacta have buds of pereiopod 2 present, and the others have buds only of pereiopod 1 . Here, we compared the first stage of the development in the family Processidae; for comparisons among other stages of the development of the genus Processa, see Ortega et al. (2005).

The first zoeal stage of $P$. fimbriata described here can be separated from the other eight species of Processa (Table 1) by means of two characters (Table 2): the presence of 4 aesthetascs on the exopod of the antennules and the presence of the anal spine. The zoea I of $P$. fimbriata is closer to $P$. canaliculata, $P$. compacta, $P$. edulis edulis, $P$. macrodactyla, $P$. modica modica, $P$. modica carolii, and $P$. nouveli holthuisi; these species share the presence of an anterior tubercle on the carapace, and 11 plumose setae on the margin of the antennal scale. 
To date, there are no exclusive characters in the first zoeal stage of Processidae. Among the species of this family, the zoea I of Ambidexter can be differentiated by the presence of a rostrum, and the resemblance of Nikoides and Processa, previously reported for adults, is now confirmed for the larval morphology.

Acknowledgments Support for this study was provided by Grants from the São Paulo Research Foundation-FAPESP (individual 1998/07454-5; Temático Biota 2010/50188-8; and Coleções Científicas 2009/54931-0) and the Conselho Nacional de Desenvolvimento Científico e Tecnológico-CNPq (301359/2007-5; 473050/2007-2; 302748/2010-5; and 471011/2011-8) to FLM. MT thanks FAPESP for an ongoing postdoctoral fellowship (2011/11901-3). Special thanks are due to Renata Biagi and Andrea Meireles for their help to FLM during field activities and collection of the ovigerous female of Processa fimbriata and to Dr. Janet Reid (JWR Associates) for providing the English review service. The comments and suggestions of the anonymous reviewers helped to improve the quality of the manuscript. The collections of species conducted in this study complied with current applicable state and federal laws of Brazil (DIFAP/ IBAMA/126/05; permanent license to FLM for collection of Zoological Material No. 11777-1 MMA/IBAMA/SISBIO; Secretaria do Meio Ambiente do Estado de São Paulo, IBAMA and Parque Estadual da Ilha Anchieta—sampling permission Proc. 42358/98).

\section{References}

Barnich R (1996) The larvae of the Crustacea Decapoda (excl. Brachyura) in the plankton of the French Mediterranean coast. Cuvillier Verlag, Göttingen

Bracken HD, De Grave S, Felder DL (2009) Phylogeny of the infraorder Caridea based on mitochondrial and nuclear genes (Crustacea: Decapoda). In: Martin JW, Crandall KA, Felder DL (eds) Decapod Crustacean phylogenetics, Crustacean issues, vol 18. CRC Press, Taylor \& Francis Group, Boca Raton, London, pp 281-308

Chace FA Jr (1997) The caridean shrimps (Crustacea: Decapoda) of the Albatross Philippine Expedition, 1907-1910, Part 7: families Atyidae, Eugonatonotidae, Rhynchocinetidae, Bathypalaemonellidae, Processidae, and Hippolytidae. Smithson Contrib Zool 587:1-106

Christoffersen ML (1998) Malacostraca, Eucarida, Caridea, Crangonoidea and Alpheoidea (except Glyphocrangonidae and Crangonidae). In: Young PS (ed) Catalogue of Crustacea of Brazil. Museu Nacional, Rio de Janeiro, Série Livros no 6, pp 351-372

Clark PF, Calazans DK, Pohle GW (1998) Accuracy and standardization of brachyuran larval descriptions. Invertebr Reprod Dev 33(2-3):127-144
De Grave S, Fransen CHJM (2011) Carideorum catalogus: the recent species of the dendrobranchiate, stenopodidean, procarididean and caridean shrimps (Crustacea: Decapoda). Zool Meded 89(5): 195-589

dos Santos A (1999) Larvas de crustáceos decápodes ao largo da costa portuguesa. PhD thesis, University of Lisbon, Portugal

Fincham AA, Williamson DI (1978) Crustacea Decapoda: Larvae. VI. Caridea: Families Palaemonidae and Processidae. Fich. Ident. Zooplancton 159/160, 8 pp

González-Gordillo JI, Rodríguez A (2000) First larval stage of Scyllarus posteli Forest, 1963 and Processa macrodactyla Holthuis, 1952 hatched in the laboratory (Crustacea, Decapoda). Ophelia 53(2):91-99

Gurney R (1923) The larval stages of Processa canaliculata Leach. J Mar Biol Assoc UK 13(1):245-265

Gurney R (1936) Notes on some decapod Crustacea of Bermuda. IIIV. Proc Zool Soc Lond 106(3):619-630

Gurney R (1937) Notes on some decapod Crustacea from the Red Sea. I. The genus Processa. Proc Zool Soc Lond 107:85-98

Gurney R (1942) Larvae of decapod Crustacea. Ray Society, London

Jagadisha K, Sankolli KN (1977) Larvae of the processid shrimp Processa barnardi Hayashi (Crustacea, Decapoda) cultured in the laboratory. In: Proceedings of the symposium on warm water zooplankton, special publication, pp 601-612

Landeira JM, Lozano-Soldevilla F, González-Gordillo JI (2009) Morphology of first seven larval stages of the striped soldier shrimp, Plesionika edwardsii (Brandt, 1851) (Crustacea: Decapoda: Pandalidae) from laboratory reared material. Zootaxa 1986:51-66

Lebour MV (1936) Notes on the Plymouth Processa (Crustacea). Proc Zool Soc Lond 106(3):609-617

Manning RB, Chace FA Jr (1971) Shrimps of the family Processidae from the northwestern Atlantic Ocean (Crustacea: Decapoda: Caridea). Smithson Contrib Zool 89:1-41

Ortega A, Queiroga H, González-Gordillo JI (2005) Planktonic stages of Processa macrodactyla (Decapoda: Caridea: Processidae) reared in the laboratory. J Mar Biol Assoc UK 85:1449-1460

Terossi M, Cuesta JA, Wehrtmann IS, Mantelatto FL (2010) Revision of the larval morphology (Zoea I) of the family Hippolytidae (Decapoda, Caridea), with a description of the first stage of the shrimp Hippolyte obliquimanus Dana, 1852. Zootaxa 2624:49-66

Williamson DI (1980) Larval development in a species of Ambidexter Manning \& Chace (Decapoda, Caridea, Processidae). Crustaceana 39(3):235-246

Williamson DI, Rochanaburanon T (1979) A new species of Processidae (Crustacea, Decapoda, Caridea) and the larvae of the north European species. J Nat Hist 13:11-33 